\title{
INTRODUCTION
}

\section{Drivers of dynamics of small pelagic fish resources: biology, management and human factors}

\author{
Jürgen Alheit ${ }^{1, *}$, Myron A. Peck $^{2}$ \\ ${ }^{1}$ Leibniz Institute for Baltic Sea Research, Seestraße 15, 18119 Warnemünde, Germany \\ ${ }^{2}$ Institute for Marine Ecosystem and Fisheries Science (IMF), Center for Earth System Research and Sustainability (CEN), \\ University of Hamburg, Große Elbstraße 133, 22767 Hamburg, Germany
}

\begin{abstract}
Populations of small pelagic fish (SPF) such as sardine, anchovy, herring, capelin and mackerel provide $\sim 25 \%$ of the global annual yield of capture fisheries, and the well-being of many human coastal communities around the world, particularly in developing countries, critically depends on these SPF resources. These fishes display large 'boom and bust' cycles with great ecological as well socioeconomic consequences. Despite many internationally coordinated research efforts, sufficient knowledge about the drivers of SPF population dynamics and, particularly, the interactive effects of environmental and anthropogenic factors is lacking. The ecology and management of SPF were discussed in a symposium in Victoria, BC (Canada), attracting participants from 31 countries. This Theme Section consists of 22 research contributions providing fundamental insights into (1) the biology of SPF, (2) the drivers of SPF dynamics and (3) the socioeconomic impacts of SPF fisheries. Such insights are urgently needed for effective, ecosystem-based management of these highly variable fish populations. The symposium was an important catalyst for future, internationally coordinated research efforts to further advance our knowledge on the drivers of SPF population dynamics and the effective management of SPF fisheries.
\end{abstract}

KEY WORDS: Small pelagic fish - Recruitment - Growth - Food web dynamics - Management · Assessment $\cdot$ Socioeconomic aspects

\section{INTRODUCTION}

Populations of small pelagic fish (SPF), also called forage fish, such as sardine, anchovy, herring, capelin and mackerel, provide about $25 \%$ of the total annual yield of capture fisheries world-wide, and the well-being of many coastal communities around the world, particularly in developing countries, critically depends on these resources (FAO 2017). Populations of SPF exhibit extreme fluctuations in abundance and geographic distribution due to the impact of environmental factors, which are often amplified by anthropogenic influences. Despite many internationally coordinated research efforts (e.g. Checkley et al.

${ }^{*}$ Corresponding author: juergen.alheit@web.de
2010, Pikitch et al. 2012, Peck et al. 2014), we still do not have sufficient knowledge about the drivers of the population dynamics of SPF, particularly how environmental and anthropogenic factors interact to affect populations of SPF.

In 1983, the Food and Agriculture Organization of the United Nations (FAO) and Intergovernmental Oceanographic Commission (IOC) organized an international symposium entitled 'The expert consultation to examine changes in abundance and species composition of neritic fish resources' in San José, Costa Rica. The research presented at that symposium was published in a 3-volume FAO Fisheries Report (Sharp \& Csirke 1983a,b, Csirke \& Sharp

() The authors 2019. Open Access under Creative Commons by Attribution Licence. Use, distribution and reproduction are unrestricted. Authors and original publication must be credited. 
1984). The 1983 symposium was a major success and inspired many research efforts conducted on SPF over the next 3 decades. As there has been no global symposium on SPF since 1983 and no international platform for the global exchange of information on SPF since the end of the International GeosphereBiosphere programme 'GLOBEC' (Global Ocean Ecosystem Dynamics) in 2008, the International Council for the Exploration of the Sea in the Atlantic (ICES) and its sister organization in the Pacific (PICES) organized an international symposium on 'Drivers of dynamics of small pelagic fish resources' in Victoria, BC (Canada), from 6 to 11 March 2017 (www.pices.int/smallpelagics2017). The symposium attracted 237 participants from 31 countries and 6 continents, consisting of physical oceanographers, plankton experts, fish biologists, fisheries experts, economists and social scientists. Approximately $18 \%$ of all attendees were students or early career researchers. Most of the presentations are available at http://meetings.pices.int/publications/presentations/ 2017-Pelagics (other authors did not give permission for posting). The symposium was organized in 6 themes: (1) environmental control of spatio-temporal changes in population size, distribution and migration of small pelagic fish in the ecosystem context; (2) external drivers of change in early life history, growth and recruitment processes; (3) the role of small pelagic fish in food web dynamics between plankton and top predators; (4) comparison of methods for assessment of small pelagic fish populations; (5) future challenges for ecosystem-based management of highly variable fish populations; (6) small pelagic fish and humans - social, economic and institutional dimensions. Contributions to the first topic were separately published in a Special Issue of DeepSea Research II (Alheit et al. 2019), research contributing to themes 2-6 is published within this Theme Section. Collectively, all of the papers stemming from the 2017 symposium have advanced our knowledge not only of the ecology and drivers of SPF populations but also the consequences of changes in SPF to human communities.

\section{DRIVERS OF SPF POPULATIONS}

\subsection{External drivers of the growth and recruitment of early life stages}

The size of populations of SPF can display particularly large fluctuations at interannual, decadal and multidecadal scales. Large oscillations in abundance (from extremely low - close to local extinction - to high levels) have occurred well prior to the development of industrial fisheries in the second half of the $20^{\text {th }}$ century (Baumgartner et al. 1992). The fluctuations also appear independent of the trophodynamic structure of ecosystems, with 'boom and bust' cycles documented in SPF populations inhabiting not only eastern boundary upwelling systems but also higherlatitude, spring-bloom dominated ecosystems in temperate and sub-polar areas (Toresen \& Ostvedt 2008, Peck et al. 2013). These rapid changes in productivity are due to the fact that SPF are r-selected species that display high rates of somatic growth, early maturation and tight coupling to climate-driven variability in prey resources (phytoplankton and zooplankton). Due to these population dynamics, many of the key hypotheses on how environmental factors regulate the recruitment (year-class) success of marine fish have been based on research conducted on species of SPF such as Atlantic herring (Hjort's critical period; Hjort 1914), northern anchovy (Lasker's 'stable ocean' hypothesis; Lasker 1981) and sardines and anchovies in upwelling systems (Cury and Roy's 'optimal environmental window' hypothesis; Cury \& Roy 1989) as reviewed by Houde (2008). A series of papers in this Theme Section has advanced our knowledge on how environmental factors regulate SPF populations via impacts on eggs, larvae and/or juveniles and contribute to differences in general life history traits.

In a study examining newly spawned eggs in Peruvian anchovy Engraulis ringens, Castro et al. (2019, this Theme Section [TS]) demonstrated how differences in the maternal provision of free amino acids can modulate the specific gravity and depth of buoyancy of eggs spawned in contrasting habitats in northern and central Chile. Slotte et al. (2019, this TS) demonstrated that larvae of Norwegian spring spawning herring Clupea harengus, which hatched relatively early in the year, grew more slowly but had a higher probability of survival by drifting more rapidly through predator fields prior to spring warming. That result contradicts the growth-survival hypothesis, which states that faster growing larvae have a higher probability of survival than more slowly growing conspecifics. In a second study examining larvae, Yebra et al. (2019, this TS) described how molecular techniques (multiplex PCR) can be applied to identify species of nauplii and protists ingested by European sardine Sardina pilchardus in the SW Mediterranean Sea. Two studies within this Theme Section examined processes impacting the growth and survival of post-larval (age-0) juveniles. Working on Pacific herring C. pallasi in the Strait of Georgia, Boldt et al. 
(2019, this TS) illustrated how bottom-up and topdown processes can affect juvenile abundance and somatic condition. In a second study targeting juveniles, de Carvalho-Souza et al. (2019, this TS) reported how anthropogenic (freshwater discharge and turbidity) and natural (temperature and prey abundance) factors influence the abundance of European anchovy $E$. encrasicolus within an estuarine nursery area. Based on long-term common-garden rearing of Norwegian (C. harengus harengus) and Baltic herring ( $C$. harengus membras) and their hybrids, Berg et al. (2019, this TS) demonstrated that genetic origin and salinity history influence reproductive success. Using a full life-cycle bioenergetics model forced by temperature and zooplankton, Huret et al. (2019, this TS) simulated European anchovy inhabiting 3 contrasting areas (North Sea, Bay of Biscay and Mediterranean Sea) to better understand which factors drive regional differences observed in their life history traits, such as growth and reproduction. Finally, Somarakis et al. (2019, this TS) compared patterns of recruitment fluctuations of clupeoid stocks on a global basis, providing new insights on SPF recruitment in relation to spawning stock, egg production and larval survival.

\subsection{The role of SPF in food web dynamics between plankton and top predators}

SPF feed on phyto- and zooplankton and are, at the same time, the main prey items for many predators such as piscivorous fish, mammals and birds. Hence, they are important controls of the energy transfer within marine food webs from plankton to top predators (Cury et al. 2000, Fréon et al. 2009). The overarching question of this symposium theme was: what do we know about the feeding habits of SPF on plankton, and, in turn, what is known about the feeding habits of the predators of SPF? Using satellite chlorophyll concentration, Menon et al. (2019, this TS) evaluated the influence that phytoplankton biomass variation has on the dynamics of the Indian oil sardine Sardinella longiceps in the southeastern Arabian Sea off the southwest coast of India. In the northern Californian Current system, during the unprecedented warming event in 2015-2016, a suite of SPF shifted from a normally interannually variable diet consisting mostly of crustacean prey to a more consistent diet with important contributions from energetically less valuable gelatinous prey sources (Brodeur et al. 2019, this TS). Also in the California Current ecosystem, Rykaczewski (2019, this TS) ana- lyzed the size spectra of plankters across a trophic gradient and suggested that adult northern anchovy (Engraulis mordax) may be restricted to the eutrophic inshore habitat. Upwelling conditions in these inshore habitats enhance nutrient availability and increase the abundance of large phytoplankters which, in turn, support higher relative abundances of large mesozooplankters. In contrast, sardine (Sardinops sagax) are able to grow well under moderately oligotrophic, offshore conditions where the relative contribution of small zooplankters is greater. In another study, Wise et al. (2019, this TS) examined amounts of SPF caught by fisheries and consumed by predators in Portuguese waters to provide advice on marine spatial planning. Whereas SPF landings of the Portuguese purse seine fishery and SPF consumption by 6 of their top mammalian and avian predators were of the same order of magnitude, spatial overlap between the fishery and its main target species, sardine (Sardina pilchardus), was relatively low (Wise et al. 2019). Finally, Louzao et al. (2019, this TS) examined how oceanographic features and the abundance of juvenile European anchovy impacted the spatial habitat utilization of 2 avian predators of SPF, the sooty (Ardenna grisea) and great shearwaters (A. gravis), both of which migrate through the Bay of Biscay during autumn.

\subsection{Comparison of methods for assessment of SPF populations}

Due to their unique population dynamics, roles in the food web and importance to both small-scale (artisanal) and large-scale (industrial) fisheries, the stock assessment and management of SPF pose unique challenges. These include the need to account for elements of the ecosystem directly as part of assessments and to apply management actions that are not only ecologically sustainable but also minimize impacts on social and economic systems. These challenges were highlighted within 3 articles of this Theme Section. Baker et al. (2019, this TS) provide new insights on life history patterns of Pacific sand lance Ammodytes personatus, with application to fisheries management, ecological interactions and comparative analyses to other regions. Sánchez et al. (2019, this TS) describe the bio-economic impact assessment of alternative harvest control rules in developing a management plan for European anchovy in the Bay of Biscay and show how the modeling work was adapted as new biological information and data sources became available. Ichinokawa \& Oka- 
mura (2019, this TS) analyzed the success of the effort management of a purse seine fishery targeting chub mackerel Scomber japonicus in Japanese waters.

\subsection{Future challenges for ecosystem-based management of highly variable fish populations}

Management of SPF stocks needs to consider both the effects of ecosystem processes on stock productivity and the combination of that productivity and exploitation on the rest of the ecosystem. Consequently, assessment models for SPF need to depict, with sufficient accuracy, how stock productivity is linked to changes in environmental drivers. Coll et al. (2019, this TS) applied qualitative mathematical modelling to describe the food web of SPF in the northwestern Mediterranean Sea and assessed the likely role of potential pressures on SPF populations, thereby comparing different hypotheses. Watari et al. (2019, this TS) constructed an Ecopath model for the food web of western North Pacific waters off Japan (Kuroshio and Oyashio Currents), focusing on SPF. Kaplan et al. (2019, this TS) developed a multimodel approach using 3 ecosystem models (Ecopath, MICE [models of intermediate complexity] and Atlantis) to understand the role of Pacific sardine in the California Current food web. Finally, using an Ecopath model, Veiga-Malta et al. (2019, this TS) provide a first representation of the trophodynamic structure and function of the Portuguese continental shelf ecosystem, highlighting the role of European sardine Sardina pilchardus in food web dynamics.

\subsection{SPF and humans - social, economic and institutional dimensions}

Fisheries for SPF have a high economic value because of (1) their use for human consumption, (2) their use for production of fish meal and fish oil and (3) their pivotal role in sustaining fisheries for large predators. These fisheries are not only critically important in terms of future global food security but are also pivotal for the economies of small fishing communities, as demonstrated by 2 contributions to this Theme Section. Lam et al. (2019, this TS) introduce an innovative value- and ecosystem-based management approach to Pacific herring dynamics and apply it to the fishery conflict between indigenous communities and the commercial fishing industry in British Columbia, Canada. Schuhbauer et al. (2019, this TS) assess the economic viability of a Mexican small- scale fishery by using estimates of total revenue from fishing, total costs of fishing and fisheries subsidies for small-scale and large-scale fisheries; they suggest ways for improving the economic viability of smallscale fisheries on SPF and other species.

\section{CONCLUSIONS}

The 2017 symposium in Victoria, BC, presented the state of the art in research on SPF and, by emphasizing new methods and approaches, provided a deeper understanding of the drivers of the dynamics of SPF resources, as exemplified by the articles in both this Theme Section and another Special Issue (Alheit et al. 2019). The symposium provided a forum for discussion of common challenges that exist across regions and species in the effective stewardship of SPF resources, especially in understanding the drivers of changes in recruitment required for ecosystembased management. The aim of the symposium was to revitalize global international cooperation on investigations of SPF. Towards this goal, the attendees were encouraged to develop an international cooperative framework, including regular future symposia, to identify and investigate unresolved questions in relation to SPF. The first steps towards this goal have already been undertaken by cooperative actions of PICES and ICES.

Acknowledgements. We thank the primary international sponsors of the symposium, PICES and ICES, and the local sponsor, Fisheries and Oceans Canada, for organizing the event. Additional support was received from the Fisheries Research and Education Agency of Japan, the Food and Agriculture Organization of the United Nations, the General Fisheries Commission for the Mediterranean, the Marine Ingredients Organization (IFFO), the Integrated Marine Biogeochemistry and Ecosystem Research Programme, the Institut de Recherche pour le Développement in France, the Japanese Society of Fisheries Oceanography, the Japanese Society of Fisheries Science, the USA NOAA-National Marine Fisheries Service, the North Pacific Fisheries Commission, the North Pacific Research Board, the Scientific Committee on Oceanic Research, and the World Wildlife Fund Canada. Without their generous support, the symposium and this Theme Section of articles would not have been possible. We are also grateful for the hard work of the other Guest Editors of this Theme Section: Arnaud Bertrand, Richard Brodeur, Susana Garrido, Martin Quaas, David Reid, Dominique Robert, Stelianos Somarakis, Akinori Takasuka, Olivier Thébaud and Verena Trenkel.

\section{LITERATURE CITED}

Alheit J, Rykaczewski RR, Sundby S, Di Lorenzo E (eds) (2019) Drivers of dynamics of small pelagic fish re- 
sources: environmental control of long-term changes. Deep Sea Res II (Special Issue) 159:1-182 www.science direct.com/journal/deep-sea-research-part-ii-topicalstudies-in-oceanography/vol/159/suppl/C

Baker MR, Matta ME, Beaulieu M, Paris N and others (2019) Intra-seasonal and inter-annual patterns in the demographics of sand lance and response to environmental drivers in the North Pacific. Mar Ecol Prog Ser 617-618: 221-224

Baumgartner T, Soutar A, Ferreira V (1992) Reconstruction of the history of Pacific sardine and northern anchovy populations over the past two millennia from sediments of the Santa Barbara Basin, California. Calif Coop Oceanic Fish Invest Rep 33:24-40

Berg F, Slotte A, Andersson L, Folkvord A (2019) Genetic origin and salinity history influence the reproductive success of Atlantic herring. Mar Ecol Prog Ser 617-618: 81-94

Boldt JL, Thompson M, Rooper CN, Hay DE and others (2019) Bottom-up and top-down control of small pelagic forage fish: factors affecting age-0 herring in the Strait of Georgia, British Columbia. Mar Ecol Prog Ser 617-618: 53-66

Brodeur RD, Hunsicker ME, Hann A, Miller TW (2019) Effects of warming ocean conditions on feeding ecology of small pelagic fishes in a coastal upwelling ecosystem: a shift to gelatinous food sources. Mar Ecol Prog Ser 617618:149-163

Castro LR, Claramunt G, Espinoza R, Azocar C, Soto-Mendoza S, Krautz MC, Pantoja S (2019) Vertical distribution, specific gravity, and free amino acids in anchoveta Engraulis ringens eggs under contrasting spawning habitat conditions. Mar Ecol Prog Ser 617-618:7-24

* Checkley D, Alheit J, Oozeki Y, Roy C (2010) Climate change and small pelagic fish. Cambridge University Press, Cambridge

Coll M, Albo-Puigserver M, Navarro J, Palomera I, Dambacher JM (2019) Who is to blame? Plausible pressures on small pelagic fish population changes in the northwestern Mediterranean Sea. Mar Ecol Prog Ser 617-618: $277-294$

Csirke J, Sharp GD (1984) Reports of the Expert Consultation to examine changes in abundance and species composition of neritic fish resources. San José, Costa Rica, 18-29 April 1983. A preparatory meeting for the FAO World Conference on fisheries management and development. FAO Fish Rep 291, Vol 1. www.fao.org/3/ x6849e/x6849e00.htm

Cury P, Roy C (1989) Optimal environmental window and pelagic fish recruitment success in upwelling areas. Can J Fish Aquat Sci 46:670-680

* Cury P, Bakun AJ, Crawford R, Jarre A, Quiñones RJ, Shannon L, Verheye, H (2000) Small pelagics in upwelling systems: patterns of interaction and structural changes in "wasp-waist" ecosystems. ICES J Mar Sci 57:603-618

de Carvalho-Souza GF, González-Ortegón E, Baldó F, Vilas C, Drake P, Llope M (2019) Natural and anthropogenic effects on the early life stages of European anchovy in one of its essential fish habitats, the Guadalquivir estuary. Mar Ecol Prog Ser 617-618:67-79

FAO (Food and Agriculture Organisation) (2017) Global capture production database updated to 2015 - summary information. www.fao.org/3/a-br186e.pdf

Fréon P, Arístegui J, Bertrand A, Crawford RJM and others (2009) Functional group biodiversity in eastern boundary upwelling ecosystems questions the wasp-waist trophic structure. Prog Oceanogr 83:97-106

Hjort J (1914) Fluctuations in the great fisheries of northern Europe reviewed in the light of biological research. Rapp PV Reun Cons Int Explor Mer 20:1-128

Houde ED (2008) Emerging from Hjort's shadow. J Northwest Atl Fish Sci 41:53-70

* Huret M, Tsiaras K, Daewel U, Skogen MD, Gatti P, Petitgas P, Somarakis S (2019) Variation in life-history traits of European anchovy along a latitudinal gradient: a bioenergetics modelling approach. Mar Ecol Prog Ser $617-$ 618:95-112

“ Ichinokawa M, Okamura H (2019) Properly designed effort management for highly fluctuating small pelagic fish populations: a case study in a purse seine fishery targeting chub mackerel. Mar Ecol Prog Ser 617-618:265-276

Kaplan IC, Francis TB, Punt AE, Koehn LE and others (2019) A multi-model approach to understanding the role of Pacific sardine in the California Current food web. Mar Ecol Prog Ser 617-618:304-321

Lam ME, Pitcher TJ, Surma S, Scott J and others (2019) Value- and ecosystem-based management approach: the Pacific herring fishery conflict. Mar Ecol Prog Ser 617618:341-364

Lasker R (1981) The role of a stable ocean in larval fish survival and subsequent recruitment. In: Lasker R (ed) Marine fish larvae: morphology, ecology, and relation to fisheries. University of Washington Press, Seattle, WA, p 80-87

KLouzao M, García-Barón I, Rubio A, Martínez U and others (2019) Understanding the 3D environment of pelagic predators from multidisciplinary oceanographic surveys to advance ecosystem-based monitoring. Mar Ecol Prog Ser 617-618:199-219

*Menon NN, Sankar S, Smitha A, George G, Shalin S, Sathyendranath S, Platt T (2019) Satellite chlorophyll concentration as an aid to understanding the dynamics of Indian oil sardine in the southeastern Arabian Sea. Mar Ecol Prog Ser 617-618:137-147

* Peck MA, Reglero P, Takahashi M, Catalán IA (2013) Life cycle ecophysiology of small pelagic fish and climate-driven changes in populations. Prog Oceanogr 116:220-245

Peck MA, Neuenfeldt S, Essington TE, Trenkel VM and others (2014) Forage fish interactions: a symposium on creating the tools for ecosystem-based management of marine resources. ICES J Mar Sci 71:1-4

Pikitch E, Boersma PD, Boyd IL, Conover DO and others (2012) Little fish, big impact: managing a crucial link in ocean food webs. Lenfest Ocean Program, Washington, DC

Krykaczewski RR (2019) Changes in mesozooplankton size structure along a trophic gradient in the California Current Ecosystem and implications for small pelagic fish. Mar Ecol Prog Ser 617-618:165-182

* Sánchez S, Ibaibarriaga L, Uriarte A, Prellezo R and others (2019) Challenges of management strategy evaluation for small pelagic fish: the Bay of Biscay anchovy case study. Mar Ecol Prog Ser 617-618:245-263

* Schuhbauer A, Cisneros-Montemayor AM, Chuenpagdee R, Sumaila UR (2019) Assessing the economic viability of small-scale fisheries: an example from Mexico. Mar Ecol Prog Ser 617-618:365-376

Sharp GD, Csirke J (1983a) Proceedings of the Expert Consultation to examine changes in abundance and species of neritic fish resources. San José, Costa, Rica, 18-29 
April 1983. A preparatory meeting for the FAO World Conference on fisheries management and development. FAO Fish Rep 291, Vol 2. www.fao.org/3/x6850b/X6850 B00.htm

Sharp GD, Csirke J (1983b) Proceedings of the Expert Consultation to examine changes in abundance and species of neritic fish resources. San José, Costa, Rica, 18-29 April 1983. A preparatory meeting for the FAO World Conference on fisheries management and development. FAO Fish Rep 291, Vol 3. www.fao.org/3/a-x6851b.pdf

Slotte A, Husebø $\AA$, Berg F, Stenevik EK and others (2019) Earlier hatching and slower growth: a key to survival in the early life history of Norwegian spring spawning herring. Mar Ecol Prog Ser 617-618:25-39

Somarakis S, Tsoukali S, Giannoulaki M, Schismenou E, Nikolioudakis N (2019) Spawning stock, egg production and larval survival in relation to small pelagic fish recruitment. Mar Ecol Prog Ser 617-618:113-136

Toresen R, Ostvedt OJ (2008) Variation in abundance of
Norwegian spring-spawning herring (Clupea harengus, Clupeidae) throughout the 20th century and the influence of climatic fluctuations. Fish Fish 1:231-256

* Watari S, Murase H, Yonezaki S, Okazaki M and others (2019) Ecosystem modeling in the western North Pacific using Ecopath, with a focus on small pelagic fishes. Mar Ecol Prog Ser 617-618:295-305

* Wise L, Galego C, Katara I, Marçalo A and others (2019) Portuguese purse seine fishery spatial and resource overlap with top predators. Mar Ecol Prog Ser 617-618:183-198

Veiga-Malta T, Szalaj D, Angélico MM, Azevedo M and others (2019) First representation of the trophic structure and functioning of the Portuguese continental shelf ecosystem: insights on the role of sardine. Mar Ecol Prog Ser 617-618:323-340

* Yebra L, Hernández de Rojas A, Valcárcel-Pérez N, Castro MC and others (2019) Molecular identification of the diet of Sardina pilchardus larvae in the SW Mediterranean Sea. Mar Ecol Prog Ser 617-618:41-52 